\title{
Minimalization of Ash from Iranian Gilsonite by Froth Flotation
}

\author{
Ramona Javadi Doodran ${ }^{1}$, Shayan Khakmardan ${ }^{1 *}$, Aref Shirazi1, Adel Shirazy² \\ ${ }^{1}$ Amirkabir University of Technology, Tehran, Iran \\ ${ }^{2}$ Shahrood University of Technology, Semnan, Iran \\ Email: *skhmardan@aut.ac.ir, *Khakmardan@sormakmine.com
}

How to cite this paper: Doodran, R.J., Khakmardan, S., Shirazi, A. and Shirazy, A. (2021) Minimalization of Ash from Iranian Gilsonite by Froth Flotation. Journal of Minerals and Materials Characterization and Engineering, 9, 1-13.

https://doi.org/10.4236/jmmce.2021.91001

Received: November 12, 2020

Accepted: December 20, 2020

Published: December 23, 2020

Copyright $\odot 2021$ by author(s) and Scientific Research Publishing Inc. This work is licensed under the Creative Commons Attribution-NonCommercial International License (CC BY-NC 4.0). http://creativecommons.org/licenses/by-nc/4.0/

\begin{abstract}
Gilsonite is a natural, brittle, and glisten tar hydrocarbon, which widely uses in the chemical, paint, and oil industry, besides asphalt production and thermal insulation. Major gangues of Gilsonite are gypsum, pyrite, silica, dolomite, calcite, and shale which are known as ash. Due to the fine liberation degree of gangue minerals from Gilsonite, most of the physical mineral processing methods are not applicable. Gilsonite has partially a behavior like coal in flotation due to its high carbon content and the similar composition of ash. As a result, flotation is one of the best methods to decrease the ash content of Gilsonite. In this study, four factors i.e. the dosage of collector, frother, and depressant, and solid to liquid ratio in three levels were examined in flotation to reduce the ash content and increase the recovery of Gilsonite. These tests were designed with the Taguchi method by Design-Expert software. Our results showed the lowest ash content of 5.2\% was obtained in the condition which $200 \mathrm{~g} / \mathrm{t}$ Gasoil as collector, $100 \mathrm{~g} / \mathrm{t}$ MIBC as a frother, $300 \mathrm{~g} / \mathrm{t}$ sodium silicate as a depressant, and pulp density was $5 \%$ solid to liquid weight ratio.
\end{abstract}

\section{Keywords}

Gilsonite, Froth Flotation, Taguchi, Coal, Ash

\section{Introduction}

Iran has a variety of minerals and deposits [1]. There are various methods for exploring minerals and potential areas. Including remote sensing and satellite image analysis [2] [3], also data processing by geostatistical methods [4] [5] [6] geochemical behavior study of elements [7] [8] and integration of intelligent analytical methods [9] [10] [11]. Gilsonite is a natural, brittle, and glisten tar hydrocarbon, which has black color and looks like obsidian [12]. It is also 
known as asphaltum [13]. Gilsonite has a high content of asphaltene which is like other petroleum source asphaltenes [14]. Although its appearance is similar to coal, with a difference in its hardness, coal has a higher hardness than gilsonite that has a higher hardness than bitumen [15]. Gilsonite becomes dark brown color after grinding [16]. Gilsonite can be solved in aliphatic and aromatic solvents [15]. The complex molecule structure of gilsonite consists of mainly carbon, followed by hydrogen, nitrogen, sulfur, and some other minor volatile elements [16]. One of the main characteristics of Gilsonite is the high content of nitrogen besides carbonyl and phenolic groups [17]. On the other hand, the molecular weight of Gilsonite is about 3000, which gives it a semi polymer behavior [18]. This complex structure gives special properties to Gilsonite, which forms multiple applications in different industries. There are more than 160 applications for this hydrocarbon mineral, including pavement modification, insulation and anticorrosion, pigment production, well-logging cementation, paint industries, chemical industries, casting sand, explosives, battery box, rubber industry, electrodes, industrial fuels, petroleum coke, and numerous resin productions [19] [20].

Impurities of gilsonite are known as ash which remains after burning the mineral [20] [21]. Ash reduces the thermal value of any hydrocarbon including Gilsonite. Also, it could cause environmental pollution due to the formation of sulfur dioxide and hydrogen sulfide. As a result, it decreases the value and applicability of Gilsonite [17] [22]. The main problematic element in ash is sulfur presenting as pyrite, gypsum, marcasite, and sometimes an organic component. Other mineral impurities in ash usually are calcium carbonate, shale, clay minerals, calcite, dolomite, and silica [19] [23] [24]. A chemical composition of Gilsonite has about $85 \%$ carbon, $10 \%$ hydrogen, $1.5 \%$ oxygen, $0.3 \%$ sulfur, and $0.2 \%$ other elements, while its carbon contents has made up of $68.3 \%$ aliphatic carbon and 31.7\% non-aliphatic carbons [12] [14] [15] [17] [25] [26]. Based on studies by Irannejad et al., the size fraction of minus $110 \mu \mathrm{m}$ concentrates most of the gangue minerals or ash content [24] [27]. This fact shows the reason for the ineffectiveness of gravity separation methods for ash reduction from Iranian Gilsonite [27].

Most of the Gilsonite deposits and reserves are located in Australia, Canada, China, Colombia, Mexico, Iraq, Iran, Russia, the Philippines, USA, and Venezuela. Annual consumption of Gilsonite is more than $90 \mathrm{Mt}$ in the world [13] [16] [18] [25] [28]. Iranian Gilsonite deposits are mainly located in the western region of Iran, including Ilam and Kermanshah. Other deposits have been explored in the Kuhdasht-Pole Dokhtar region in Lorestan, besides Behbahan-Ramhoromoz in the Khuzestan region [24]. The main feasible deposits are located in the vicinity of Gilane Gharb, Qasre Shirin, and Ivane Gharb in the Kermanshah region near the Iraq border. Also, the Caspian oil field in the northern region of Iran, has the probability of Gilsonite deposits presence, like Baku in Azerbaijan. In addition, the Gilsonite deposits continued from Kermanshah in the western regions of Iran to the eastern regions of Iraq [24] [27] [29]. 
Gilsonite deposits typically are used unaccompanied by further processing operations in numerous industries due to their workable grade and can be named as direct shipping ores [24] [27]. However, due to the special needs of some industries to high-grade Gilsonite (i.e. low ash content) and reducing number of high-grade reserves, there is an essential need to enrich low-grade deposits and produce a Gilsonite concentrate with the minimum ash content to add value to this commodity. The need for mineral processing of raw materials is increasing day by day and many studies have been done for the development of optimal processing technology [30]. Previous research works focused more on the characterization and identification of multiple applications, while a few research works on the gravity separation methods. In this study, using surface chemistry differences between Gilsonite and other mineral fragments or gangue minerals, flotation was selected and applied to evaluate its capability of ash reduction from the run of mine ore.

Flotation is a multiplex Physico-chemical separation process that interacting between three phases of liquid, gas, and solid [31]. This method is a selective process and the effectiveness of it depends on particle-bubble interactions, including particle-bubble collision, selective attachment, and particle-bubble stability. This selective process can negatively be effected by entrainment in the water and physical entrapment of particles, this will usually happen when both gangue and valuable minerals are not fully liberated, or on the flip side, when fine particles have a diameter less than 20 microns, which can move freely by the current. So, particle size is the most critical factor in the flotation process and should be controlled in order to have high efficiency. The optimum range of particle size in flotation is from 20 to 200 microns, however for coal, it is from 75 to 150 microns, 150 to 300 microns, and 250 to 500 microns. Irannejad et al., measured 110 microns as the liberation degree of Iranian Gilsonite, also it is measured in which most of the ash content is inside the -44 microns fraction, it is including fine clay particles and silicates [32] [33].

For flotation of minerals, having a hydrophobic surface is an essential principle, different reagents are involved to give a hydrophobic surface to a mineral, including collectors, activators, $\mathrm{pH}$ modifiers, and frothers [32] [33]. All of mentioned factors are used to minimize ash of Iranian Gilsonite.

\section{Materials}

The materials for this study were prepared by Sormak mine company, which operates the Garaweh mine in the Qasre Shirin Region, west part of Iran, near the Iraq border. A $200 \mathrm{~kg}$ of sample was gathered from run of mine directly and avoided its oxidization to have a more accurate chemical analysis, after preparation including crushing, grinding, and splitting; a representative sample prepared for measuring physical and chemical properties. Physical properties were measured by ASTM (American Society for Testing and Materials) standard test methods; Chemical elemental analysis was measured by the LECO (Laboratory Equipment Corporation) analyzer under the ASTM standard test method. This 
instrument is a reliable method to determine Carbon, Hydrogen, Nitrogen, Oxygen, and Sulfur from organic and inorganic materials [34] [35]. The physical properties and element analysis of this sample are summarized in Table 1 . The location of Mine and a view of the pit are shown in Figure 1. The main gangue minerals were gypsum, calcite, dolomite, silica-based minerals, and pyrite. Also, silts, marl, and shales were other impurities in the Gilsonite sample.

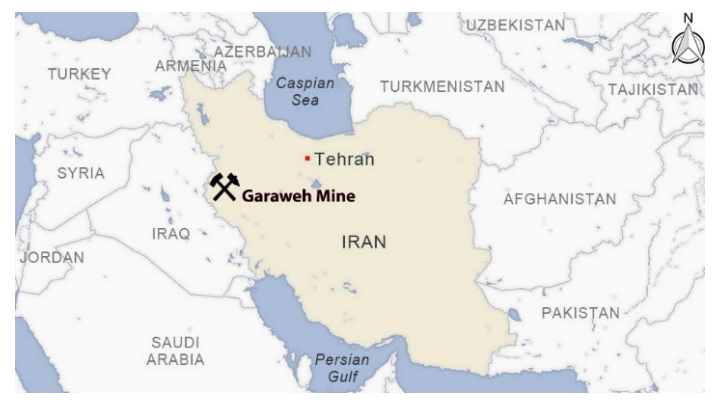

(a)

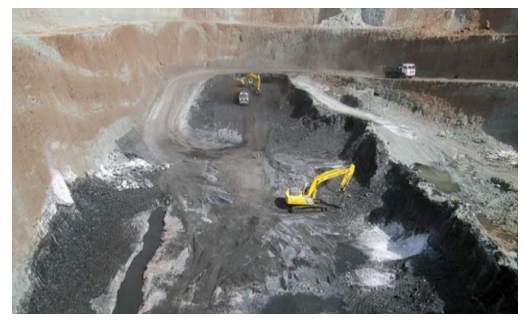

(b)

Figure 1. (a) Location and view of the Garaweh mine; (b) A view of Garaweh mine.

Table 1. Physical and chemical properties of sampled Gilsonite.

\begin{tabular}{ccc}
\hline & Physical Properties Analysis & \\
\hline Test & Result & Test Method \\
\hline Ash Content wt\% & 16.4 & ASTM-D3174 \\
Moisture Content wt\% & $<3$ & ASTM-D3173 \\
Volatile matter wt\% & 50 & ASTM-D3175 \\
Fixed carbon wt\% & 39 & ASTM-D3172 \\
Specific Gravity at $\mathbf{2 5}^{\circ} \mathrm{C}$ & 1.04 & ASTM-D3289 \\
Softening Point ${ }^{\circ} \mathrm{C}$ & 180 & ASTM-D36 \\
Penetration at $25^{\circ} \mathrm{C}$ & 0 & ASTM-D5 \\
Color in Mass (bulk) & Black & \\
Color in Powder (fine) & Brown & \\
& Element Analysis & ASTM-D5291 \\
Carbon wt\% & 74 & ASTM-D5291 \\
Hydrogen wt\% & 7.1 & ASTM-D5291 \\
Nitrogen wt\% & 0.67 & ASTM-D5291 \\
Oxygen wt\% & 3.1 & Leco Analyzer \\
Sulfur wt\% & 5.5 &
\end{tabular}




\section{Methods}

The main mineral processing method applying the surface chemistry contrast is froth flotation. Using this method, hydrophilic and hydrophobic minerals can be separated by the assist of specific chemical reagents that enhance surface properties differences, and generate value to the produced concentrate [36] [37]. In the Flotation process, there are many factors which can affect the process, including froth level, airflow rate, rotation speed, residence time, $\mathrm{pH}$ of the pulp, dilution, feed rate, chemical reagent dosage, size, and design of the cell [31] [32] [33] [38].

The sample was grinded by Raymond mill and 95\% cumulatively passing of the product was 200 mesh or 75-micron sieve. The particle size distribution results are shown in Table 2.

In this study, the effect of chemical reagent dosage and pulp density on ash rejection was evaluated as the main variables. A 6 Liter Denver D12 laboratory flotation cell was used to perform these tests. The rotation speed of the flotation cell rotor was adjusted to $1500 \mathrm{rpm}$. Feed rate, residence time, and airflow rate were kept constant in all tests, as a consequence of the same pulp density in these batch tests. Also, Calcium hydroxide was used as a $\mathrm{pH}$ modifier to maintain the $\mathrm{pH}$ of the flotation tests about 7. After the conditioning time including adding the reagents of $10 \mathrm{~min}$ for each test, the flotation test started with opening the air valve, and froth was collected for 180 seconds.

After measuring ash content which remnant of burning process, the flotation recovery was obtained according to following equation, where $C$ is the concentrate weight, $c$ is the concentrate grade (part without ash), $F$ is the feed weight and $f$ is the feed concentrate.

$$
R=\frac{C c}{F f} \times 100=\frac{C(100-\text { Ash content in concentrate })}{F(100-\text { Ash content in feed })} \times 100
$$

Coal and graphite are the hydrophobic minerals which can be floated using Gasoil as a collector, MIBC (Methyl Isobutyl Carbinol), or pine oil as a frother, and sodium silicate or dextrin as a depressant for their industrial-scale flotation [37] [39]. The selection of depressant is depending on the ash composition [39]. Main coal gangue minerals are kaolinite, quartz, pyrite, illite, calcite, ankerite, and montmorillonite, which are partially the same as gangue minerals of Gilsonite [27] [37]. Major gangues of Gilsonite are gypsum, pyrite, silica, dolomite, calcite, and shale. As a result of the aforementioned facts about Gilsonite and its

Table 2. Particle size distribution of Gilsonite flotation sample.

\begin{tabular}{cccc}
\hline $\begin{array}{c}\text { Size Fraction } \\
\mu \mathrm{m}\end{array}$ & $\begin{array}{c}\text { Size Fraction } \\
\text { mesh }\end{array}$ & $\begin{array}{c}\text { Mass } \\
\text { Wt\% }\end{array}$ & $\begin{array}{c}\text { Cumulative Pass } \\
\text { Wt\% }\end{array}$ \\
\hline+75 & +200 & 5.22 & 100 \\
+44 to 75 & +325 to 200 & 59.41 & 94.78 \\
+37 to 44 & +400 to 325 & 15.36 & 35.37 \\
-37 & -400 & 20.01 & 20.01 \\
\hline
\end{tabular}


composition similarity to coal, 9 initial experiments have been designed by Design Expert Software for 4 factors and in 3 levels by the Taguchi method to find the optimum flotation conditions in order to reduce the ash content and reach the maximum recovery of Gilsonite. The levels of these factors are summarized in Table 3. For these tests, common industrial flotation reagents of coal froth flotation were applied including Gasoil as a collector, MIBC as a frother from Chinese producer with $99 \%$ purity, and sodium silicate made in china with $99 \%$ purity as a depressant due to the composition of ash content as shown in Table 1.

\section{Results and Discussion}

Regarding to aforementioned facts and features, 9 initial tests based on the Taguchi method were performed to gain the framework of confirmation tests. The recovery and ash content of these tests has been summarized in Table 4.

The flotation results are summarized in Table 4. The increase of collector and frother besides increasing the ratio of solid to liquid causes an increase of ash in the froth phase. On the other hand, the increase in depressant dosage decreased the ash content from $16.4 \%$ to $5.2 \%$. Gasoil, as a non-ionic collector, enhances the hydrophobicity of Gilsonite particles, it forms emulsions and acts as not a selective collector due to low solubility in water. This can be the reason why ash

Table 3. Levels of factors in the initial flotation tests.

\begin{tabular}{cccc}
\hline Factor & \multicolumn{3}{c}{ Level } \\
\cline { 2 - 4 } & 1 & 2 & 3 \\
\hline Collector (ppm) & 100 & 200 & 300 \\
Frother (ppm) & 50 & 100 & 150 \\
Depressant (ppm) & 100 & 200 & 300 \\
Solid to Liquid ratio wt\% & 5 & 10 & 20 \\
\hline
\end{tabular}

Table 4. Result of flotation tests.

\begin{tabular}{ccccccc}
\hline $\begin{array}{c}\text { Test } \\
\text { No. }\end{array}$ & $\begin{array}{c}\text { Collector } \\
(\mathrm{ppm})\end{array}$ & $\begin{array}{c}\text { Frother } \\
(\mathrm{ppm})\end{array}$ & $\begin{array}{c}\text { Depressant } \\
(\mathrm{ppm})\end{array}$ & $\begin{array}{c}\text { Solid to } \\
\text { Liquid } \\
\text { Ratio } \%\end{array}$ & $\begin{array}{c}\text { Ash } \\
\text { Content } \\
\text { Wt\% }\end{array}$ & $\begin{array}{c}\text { Recovery } \\
\text { Wt\% }\end{array}$ \\
\hline 1 & 200 & 150 & 100 & 10 & 12.5 & 77.8 \\
2 & 300 & 50 & 300 & 10 & 6.5 & 50.1 \\
3 & 200 & 50 & 200 & 20 & 9.1 & 59.4 \\
4 & 100 & 100 & 200 & 10 & 8.4 & 64.8 \\
5 & 300 & 100 & 100 & 20 & 13.2 & 69.5 \\
6 & 100 & 50 & 100 & 5 & 11.1 & 68.1 \\
7 & 100 & 150 & 300 & 20 & 7.1 & 51.2 \\
8 & 300 & 150 & 200 & 5 & 9.8 & 72.6 \\
9 & 200 & 100 & 300 & 5 & 5.2 & 39.9 \\
\hline
\end{tabular}


content amplifies in concentrate with the gasoil dosage. Again, due to a non-selective collector, with the dosage of frother, react as a synergism factor, and leads a bulk flotation process. It can be amplified with the high solid to liquid ratio or in other words the high pulp density. The probability of mechanical entrapment of the gangue in the froth could increases. On the other hand, locked gangue minerals with the Gilsonite particles increase the ash content and recovery with this method. As one of the conclusions, fully dispersed gangue minerals besides the nature of Gilsonite particles, are other reasons for the ineffectiveness of current mineral processing methods to beneficiate it. For the depressant, an increasing dosage of sodium silicate depressed more carbonate, and silicate-based surfaces, and the main reason for its effectiveness can be maintaining $\mathrm{pH}$ and its consequence on the zeta potential of these minerals. The effects of parameters on the ash content of the concentrate can be seen in Figure 2. Also, the effects of these parameters on the recovery of Gilsonite particles can be seen in Figure 3.

In the coal flotation industry, due to the coal natural hydrophobicity, non-ionic collectors are being used and they enhance its hydrophobicity and to attach to air bubbles, the attachment mechanism of these collectors is based on adhesion [37] [40]. The common non-ionic collectors are Gasoil and Kerosene, which widely being used in the flotation of coal, graphite, talc, molybdenite, and sulfur

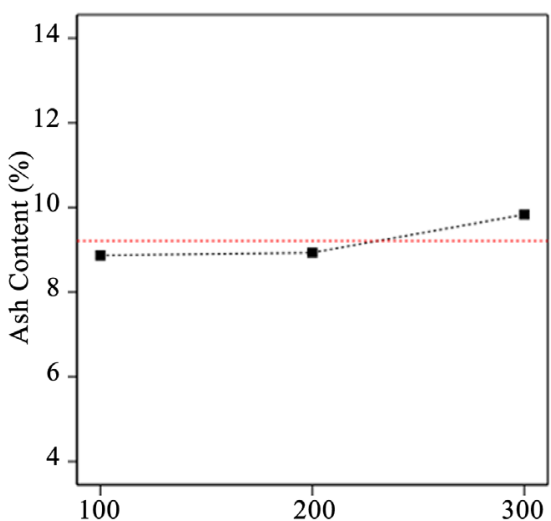

(a)

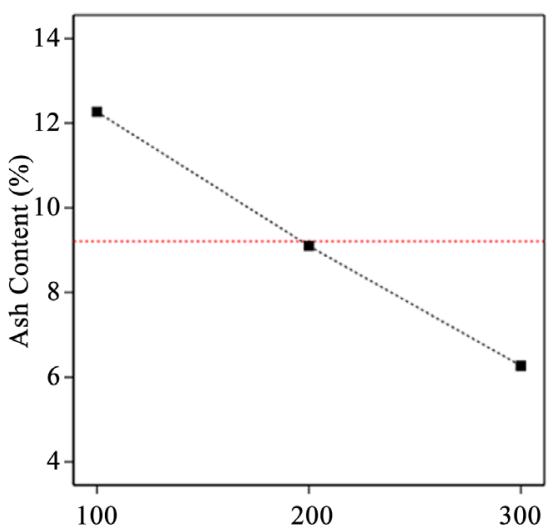

(c)

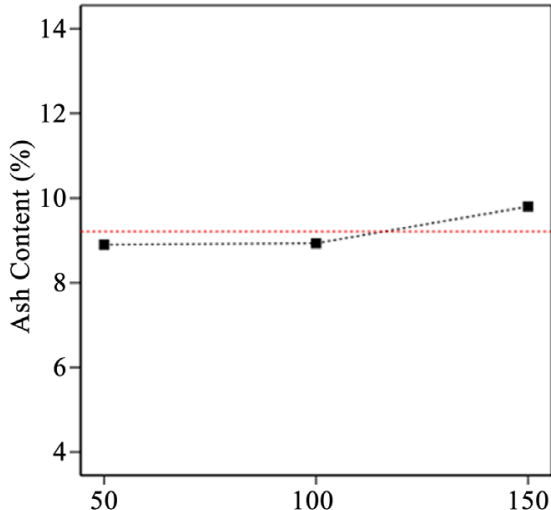

(b)

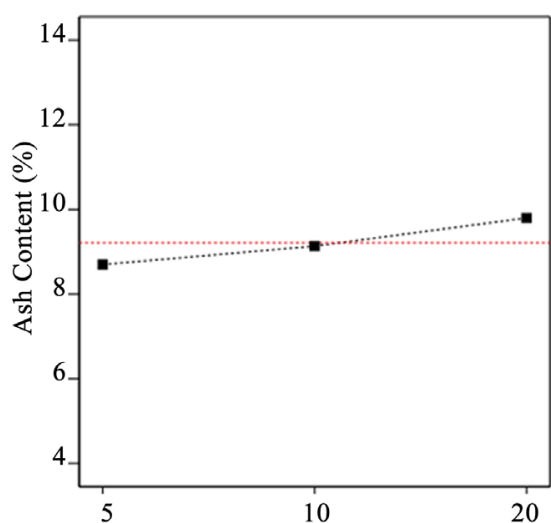

(d)

Figure 2. Effect of different flotation operation variables ((a) collector; (b) frother; (c) depressant; (d) pulp density) on the ash content of Gilsonite. 


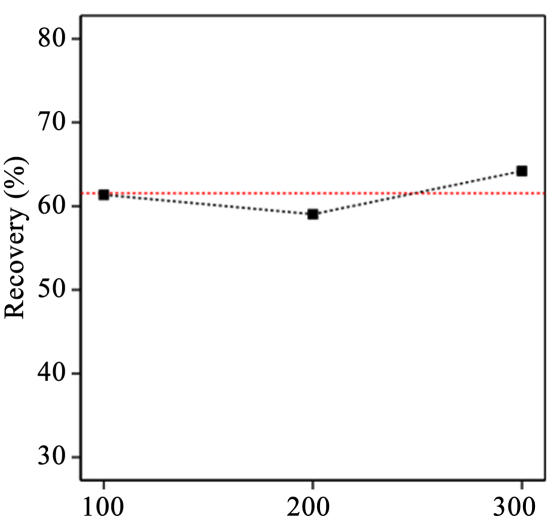

(a)

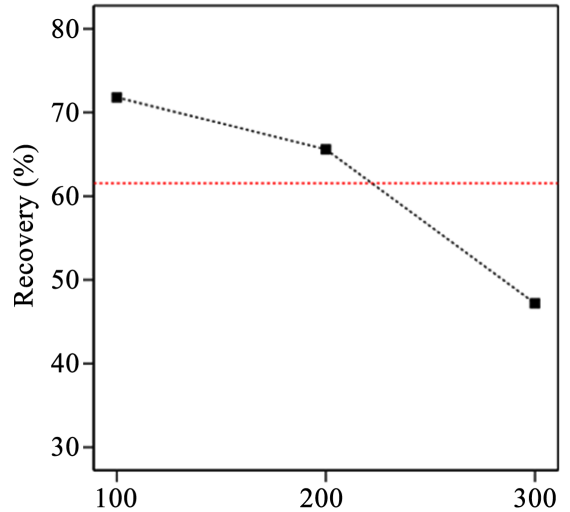

(c)

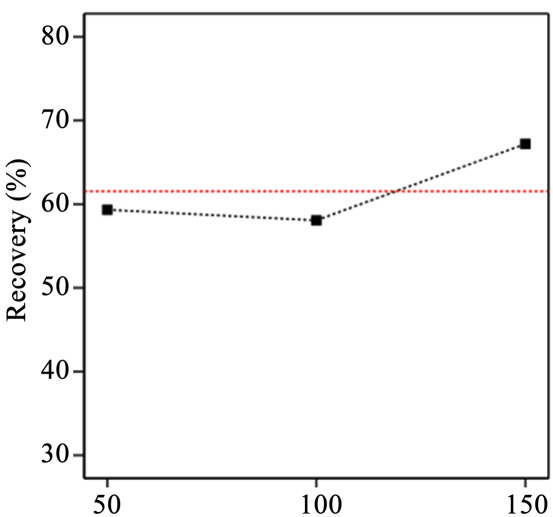

(b)

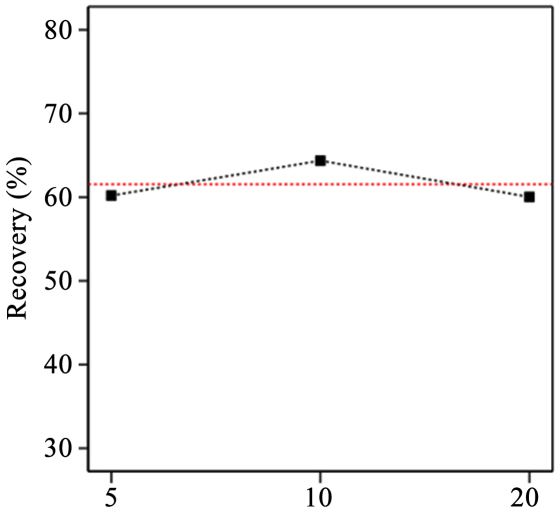

(d)

Figure 3. Effect of different flotation operation variables ((a) collector; (b) frother; (c) depressant; (d) Solid to Liquid Ratio (pulp density)) on the recovery of Gilsonite.

[36]. Frothers are surfactants that absorbed at the gas-liquid interface and forming and stabilizing the flotation froth [33]. MIBC and Pine Oil are the most common frothers in the coal flotation industry [22] [37]. Due to the high carbon content of Gilsonite, and the composition of ash content, it is expected that the same reagents can be appliable to Gilsonite and former research works, confirm this claim. On the other hand, opting type of depressant is depending on the composition of ash content, which same again, due to having silicates $\left(\mathrm{SiO}_{2}\right)$, carbonates (calcite), and sulfates (gypsum), a wide range of depressants are applicable including sodium silicate, dextrin, starch, Lime (as $\mathrm{pH}$ modifier to deactivate pyrite) [27] [36] [37]. Sodium silicate in the flotation is as effective as a depressant of quartz and calcite, between pH 5 - 8 [36]. Solid to liquid ratio or pulp density is another important factor in the efficiency of flotation, unlike metal sulfide minerals which can work with 20 to 30 percent, in coal flotation optimum solid to liquid ratio is between $7 \%$ to $12 \%$ depending on ash content [36] [37].

As shown in Figure 2 and Figure 3, the effect of collector and frother showed the same behavior on the recovery and ash content that increase slightly. With the highest dosage concentration (i.e. $300 \mathrm{ppm}$ collector, $150 \mathrm{ppm}$ frother). It can be concluded that an increase in the ash content, or the Gilsonite particles 
carrying gangue minerals in the concentrate, will result in a recovery increase. With the medium solid to liquid ratio, the recovery increased slightly (65\% from $60 \%)$ as shown in Figure 3(d). Mechanical entrapment of gangue minerals in the froth is the main reason for recovery escalating with more pulp density. Recovery reduction, with an increasing amount of depressant in the pulp, is due to stopping gangue particles that accumulating with Gilsonite particles and blocks the route of these Gilsonite particles to proceed to the froth phase.

A comparison of parameter interactions was provided for both the ash content and the recovery. As seen in Figures 4-6, former conclusions about the effects of collector, frother, depressant, and the solid to liquid ratio can be confirmed. Figures 4-6 show depressant levels play a major role in the reduction or increase of both the recovery and ash content.

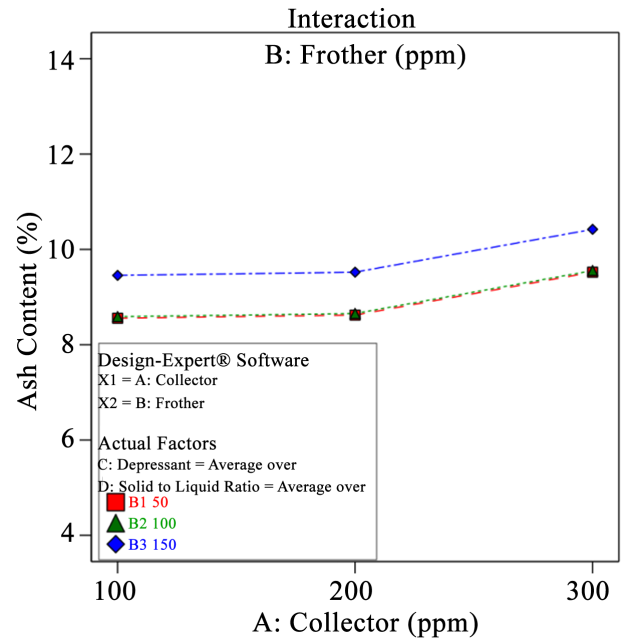

(a)

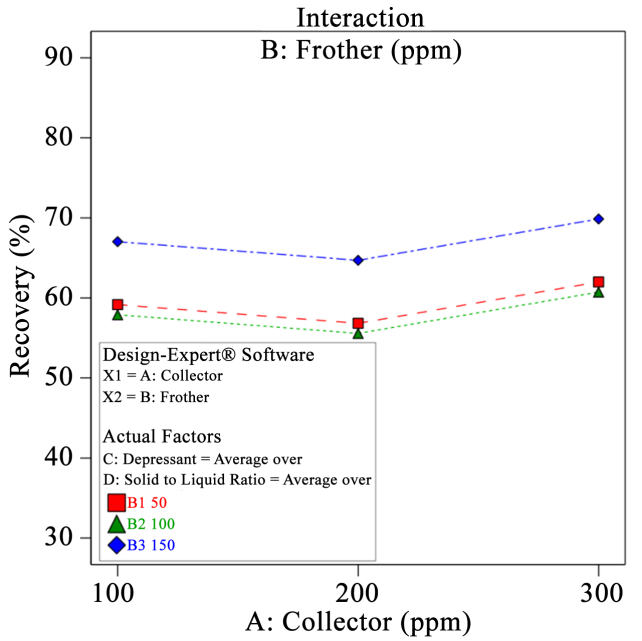

(b)

Figure 4. Comparison of collector and frother interaction for (a) ash content and (b) recovery.

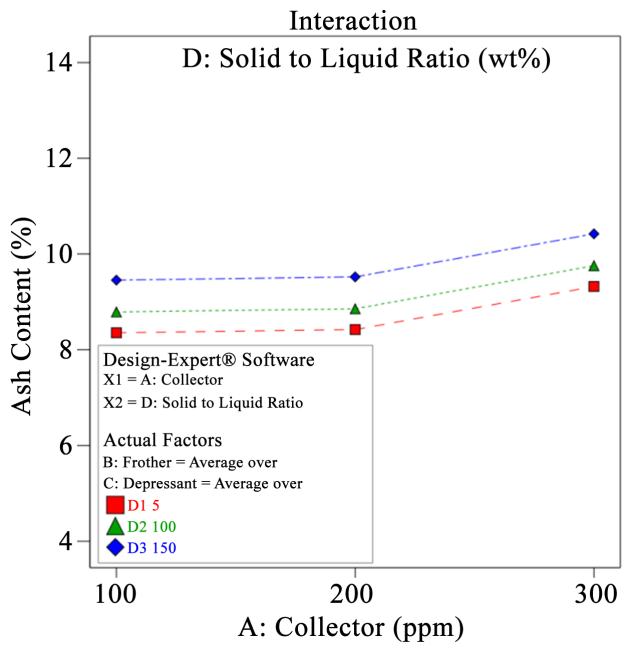

(a)

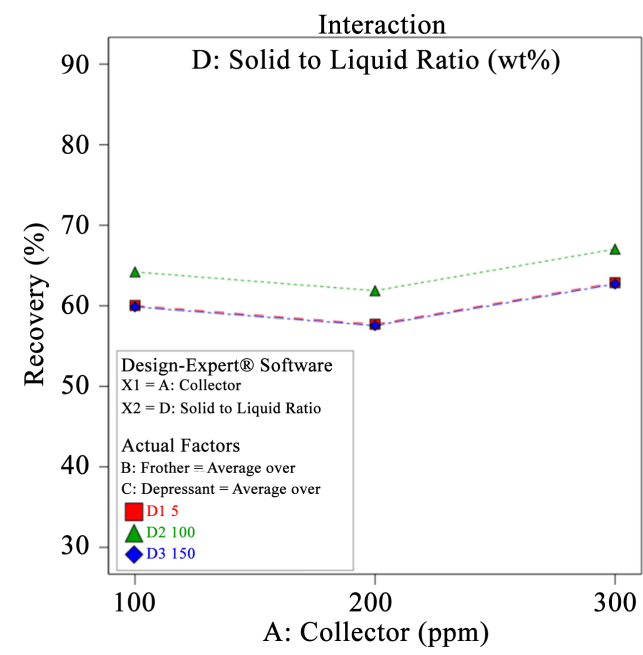

(b)

Figure 5. Comparison of collector and solid to liquid ratio interaction for (a) ash content and (b) recovery. 


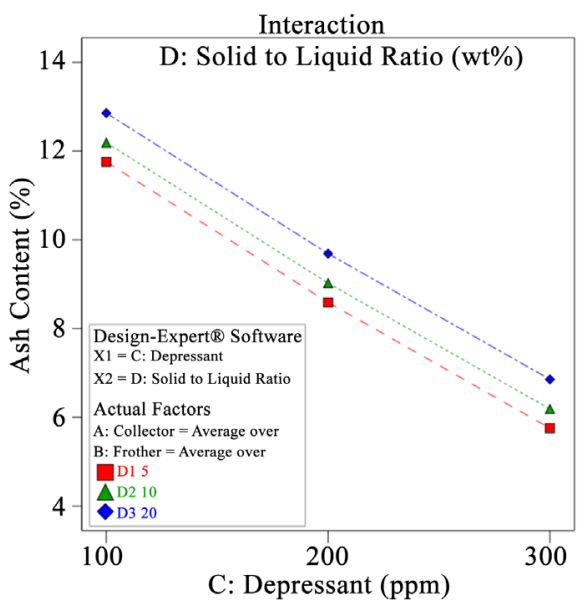

(a)

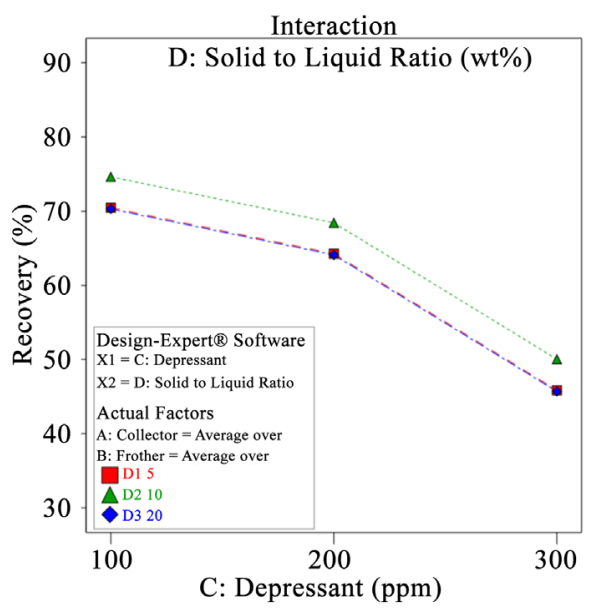

(b)

Figure 6. Comparison of depressant and solid to liquid ratio interaction for (a) ash content and (b) recovery.

\section{Conclusions}

In this study, the effect of collector, frother, and depressant dosage besides the influence of solid to liquid ratio (pulp density) on the ash content and recovery of Gilsonite was studied. Nine flotation tests designed by the Taguchi method were performed on the Gilsonite sample in order to optimize the conditions of Gilsonite flotation for reducing the ash content and increasing the recovery. Based on enrichment ratio and the ratio of concentration, test run number 9 , with $200 \mathrm{ppm}$ Gasoil as a collector, $100 \mathrm{ppm}$ MIBC as a frother, $300 \mathrm{ppm}$ Sodium Silicate as a depressant, and $5 \%$ solid to liquid ratio as pulp density, observed as the optimum test condition for $5.2 \%$ ash content and $39.9 \%$ gilsonite recovery. Also, with the concurrent increase of collector and frother, both the recovery and ash content increased, and it should be avoided on the industrial scale since the separation is non-selective. On the other hand, the most influential variable was depressant dosage, which can prevent gangue minerals to recover as a concentrate.

Reducing the ash content of gilsonite by flotation method is a simple way to add value to low-grade deposits. Moreover, by industrializing these numerous low-grade deposits, many economic and social impacts will happen to that region. All in all, flotation is a multi-factor method in which numerous Physico-chemical parameters have synergism and antagonistic effects on each other, one of the most parameters, is the particle size.

\section{Acknowledgements}

The authors would like to express their sincere gratitude to the Sormak mine company, owner of Garaweh Gilsonite mine.

\section{Conflicts of Interest}

The authors declare no conflicts of interest regarding the publication of this paper. 


\section{References}

[1] Shirazi, A. and Shirazy, A. (2020) Introducing Geotourism Attractions in Toroud Village, Semnan Province, Iran. International Journal of Science and Engineering Applications, 9, 79-86.

[2] Shirazi, A., Shirazy, A. and Karami, J. (2018) Remote Sensing to Identify Copper Alterations and Promising Regions, Sarbishe, South Khorasan, Iran. International Journal of Geology and Earth Sciences, 4, 36-52.

[3] Shirazi, A., et al. (2018) Remote Sensing Studies for Mapping of Iron Oxide Regions, South of Kerman, Iran. International Journal of Science and Engineering Applications, 7, 45-51. https://doi.org/10.7753/IJSEA0704.1002

[4] Alahgholi, S., Shirazy, A. and Shirazi, A. (2018) Geostatistical Studies and Anomalous Elements Detection, Bardaskan Area, Iran. Open Journal of Geology, 8, 697-710. https://doi.org/10.4236/ojg.2018.87041

[5] Shirazi, A., et al. (2018) Geostatistics Studies and Geochemical Modeling Based on Core Data, Sheytoor Iron Deposit, Iran. Journal of Geological Resource and Engineering, 6, 124-133. https://doi.org/10.17265/2328-2193/2018.03.004

[6] Shirazi, A., et al. (2018) Exploration Geochemistry Data-Application for Cu Anomaly Separation Based on Classical and Modern Statistical Methods in South Khorasan, Iran. International Journal of Science and Engineering Applications, 7, 39-44. https://doi.org/10.7753/IJSEA0704.1001

[7] Shirazy, A., Ziaii, M. and Hezarkhani, A. (2020) Geochemical Behavior Investigation Based on K-Means and Artificial Neural Network Prediction for Copper, in Kivi Region, Ardabil Province, Iran. Iranian Journal of Mining Engineering, 14, 96-112.

[8] Shirazi, A. and Hezarkhani, A. (2018) Predicting Gold Grade in Tarq 1:100000 Geochemical Map Using the Behavior of Gold, Arsenic and Antimony by K-Means Method. Journal of Mineral Resources Engineering, 2, 11-23.

[9] Shirazi, A., et al. (2018) Introducing a Software for Innovative Neuro-Fuzzy Clustering Method Named NFCMR. Global Journal of Computer Sciences. Theory and Research, 8, 62-69. https://doi.org/10.18844/gjcs.v8i2.3264

[10] Shirazy, A., et al. (2019) Geochemical and Geostatistical Studies for Estimating Gold Grade in Tarq Prospect Area by K-Means Clustering Method. Open Journal of Geology, 9, 306-326. https://doi.org/10.4236/ojg.2019.96021

[11] Shirazy, A., et al. (2020) Geostatistical and Remote Sensing Studies to Identify High Metallogenic Potential Regions in the Kivi Area of Iran. Minerals, 10, 869. https://doi.org/10.3390/min10100869

[12] Boden, T. and Tripp, B.T. (2012) Gilsonite Veins of the Uinta Basin, Utah. Vol. 141. Utah Geological Survey.

[13] Monson, B. and Parnell, J. (1992) The Origin of Gilsonite Vein Deposits in the Uinta Basin, Utah.

[14] Carbognani, L., Espidel, J. and Izquierdo, A. (2000) Characterization of Asphaltenic Deposits from Oil Production and Transportation Operations. In: Developments in Petroleum Science, Elsevier, Amsterdam, 335-362. https://doi.org/10.1016/S0376-7361(09)70284-5

[15] Nciri, N., et al. (2014) Chemical Characterization of Gilsonite Bitumen. Journal of Petroleum \& Environmental Biotechnology, 5, 1.

[16] Helms, J.R., et al. (2012) Structural Characterization of Gilsonite Bitumen by Advanced Nuclear Magnetic Resonance Spectroscopy and Ultrahigh Resolution Mass 
Spectrometry Revealing Pyrrolic and Aromatic Rings Substituted with Aliphatic Chains. Organic Geochemistry, 44, 21-36.

https://doi.org/10.1016/j.orggeochem.2011.12.001

[17] Jahanian, H., Shafabakhsh, G. and Divandari, H. (2017) Performance Evaluation of Hot Mix Asphalt (HMA) Containing Bitumen Modified with Gilsonite. Construction and Building Materials, 131, 156-164. https://doi.org/10.1016/j.conbuildmat.2016.11.069

[18] Kök, B.V., Yilmaz, M. and Guler, M. (2011) Evaluation of High Temperature Performance of SBS+ Gilsonite Modified Binder. Fuel, 90, 3093-3099.

https://doi.org/10.1016/j.fuel.2011.05.021

[19] Co., S.M. (2020) Gilsonite Applications. http://www.sormakmine.com/products/100

[20] Co., A.G. (2020) Gilsonite History and Applications. http://www.americangilsonite.com

[21] Ameri, M., et al. (2011) Technical Study on the Iranian Gilsonite as an Additive for Modification of Asphalt Binders Used in Pavement Construction. Construction and Building Materials, 25, 1379-1387. https://doi.org/10.1016/j.conbuildmat.2010.09.005

[22] Glover, I.T. (1980) An Introduction to Coal Technology (Berkowitz, N.). Journal of Chemical Education, 57, A244. https://doi.org/10.1021/ed057pA244.1

[23] Kogel, J.E., et al. (2006) Industrial Minerals \& Rocks: Commodities, Markets, and Uses. SME, New York.

[24] Almasi N. (2005) Bitumen Index in Ilam Province and Applied Activities on Them. 24th Geoscience Conference, Tehran, September 2005, 15-28.

[25] Vélez, J.S., Velásquez, S. and Giraldo, D. (2016) Mechanical and Rheometric Properties of Gilsonite/Carbon Black/Natural Rubber Compounds Cured Using Conventional and Efficient Vulcanization Systems. Polymer Testing, 56, 1-9.

https://doi.org/10.1016/j.polymertesting.2016.09.005

[26] Burton, D.K. (1996) A History of Uintah County: Scratching the Surface. Utah State Historical Society.

[27] Khodarahmi, A., Habibi, M. and Bahrami, A. (2006) Gilsonite Processing by Gravity Method. 25th Geoscience Conference, Tehran, November 2006, 59-67.

[28] Krahulec, K. (2008) 2008 Summary of Mineral Activity in Utah.

[29] Aflaki, S. and Tabatabaee, N. (2009) Proposals for Modification of Iranian Bitumen to Meet the Climatic Requirements of Iran. Construction and Building Materials, 23, 2141-2150. https://doi.org/10.1016/j.conbuildmat.2008.12.014

[30] Khakmardan, S., et al. (2018) Copper Oxide Ore Leaching Ability and Cementation Behavior, Mesgaran Deposit in IRAN. Open Journal of Geology, 8, 841. https://doi.org/10.4236/ojg.2018.89049

[31] Wills, B.A. and Finch, J. (2015) Wills' Mineral Processing Technology: An Introduction to the Practical Aspects of Ore Treatment and Mineral Recovery. Butterworth-Heinemann, Oxford. https://doi.org/10.1016/B978-0-08-097053-0.00001-7

[32] Fornasiero, D. and Filippov, L. (2017) Innovations in the Flotation of Fine and Coarse Particles. Journal of Physics: Conference Series, 879, Article ID: 012002. https://doi.org/10.1088/1742-6596/879/1/012002

[33] Farrokhpay, S., Filippov, L. and Fornasiero, D. (2020) Flotation of Fine Particles: A Review. Mineral Processing and Extractive Metallurgy Review.

https://doi.org/10.1080/08827508.2020.1793140 
[34] LECO Analyzer (CS844) Manual 2020. https://www.leco.com https://pdf.directindustry.com/pdf/leco/cs844-series/114499-801141.html

[35] ASTM, ASTM D3174-12 (2012) Standard Test Method for Ash in the Analysis Sample of Coal and Coke from Coal. ASTM International, West Conshohocken.

[36] Rezaei, B. (1996) Flotation. 2nd Edition, Hormozgan University Publication, Bandar Abbas.

[37] Rezaei, B. (2001) Coal Cleaning Technology. Amirkabir University of Technology Publication, Tehran.

[38] Rezai, B. (1998) Mineral Processing Technology (Beneficiation with Gravity Methods). Hormozgan University Publication, Bandar Abbas.

[39] Wei, T., Peng, Y. and Farrokhpay, S. (2014) Froth Stability of Coal Flotation in Saline Water. Mineral Processing and Extractive Metallurgy, 123, 234-240. https://doi.org/10.1179/1743285514Y.0000000077

[40] Lide, D.R. (1993) Handbook of Chemistry and Physics. CRC Press, Boca Raton, 1. 